\title{
Bilješke o Luciju Aneju Domiciju Prokulu s pulskog natpisa CIL 5, 34
}

\author{
Pregledni rad \\ Review article \\ UDK 930.27(497.5-3 Istra)“652“
}

\begin{abstract}
Natpis koji spominje Lucija Aneja Domicija Prokula, baku Antoniju Klementijanu i pradjeda Antonija Feliksa, pronađen u Puli, povod je za prozopografsku analizu, čime se osvjetljava kontekst u kojem je nastao. Antonija Klementijana dala je podići spomenik na mjestu koje je odredilo gradsko vijeće rimske Pule svom unuku Luciju, koji je bio dječačke dobi. Ovaj je $s$ jedne strane bio potomak senatorske obitelji Aneja, a s druge mu je pradjed bio Antonije Feliks, oslobođenik Antonije Mlađe, majke cara Klaudija, koji je sredinom I. stoljeća bio namjesnik provincije Judeje. Ne može se isključiti da je obitelj Antonija imala zemljišne posjede u južnoj Istri, iako je ovdje sigurno posvjedočena nazočnost samo njihovih moćnih oslobođenika i njihovih potomaka (Antonia Clementiana, Antonia Caenis, ali i još šest „anonimnih“, vjerojatno oslobođenika ove dvije rimske matrone).
\end{abstract}

Ključne riječi: Istra, antika, epigrafija, prozopografija, Antonia Minor, Anneii

Dočetkom XIX. stoljeća u Puli je, ad templum Augusti, pronađen lijepo sačuvani kameni blok od vapnenca, oblikovan kao postolje kipa (basis) s počasnim natpisom na prednjoj strani, uklesanim velikim pravilnim slovima (CIL 5, 34; Inscr. It. 10, 1, 39; Alföldy 1984, 79, Nr. 11; Alföldy 1999, 285, Nr. 10; HD032972; EDR 093929). Čuvao se u Arheološkom muzeju Istre, a danas se nalazi u muzejskoj zbirci na Brijunima:

\author{
L. Anne \\ io L(uci) f(ilio) \\ Domitio \\ Proculo \\ $c$ (larissimo) p(uero) \\ pronepoti \\ Antoni \\ Felicis \\ Antonia \\ Clementiana \\ avia
}

I(oco) d(ato) d(ecreto) d(ecurionum) 


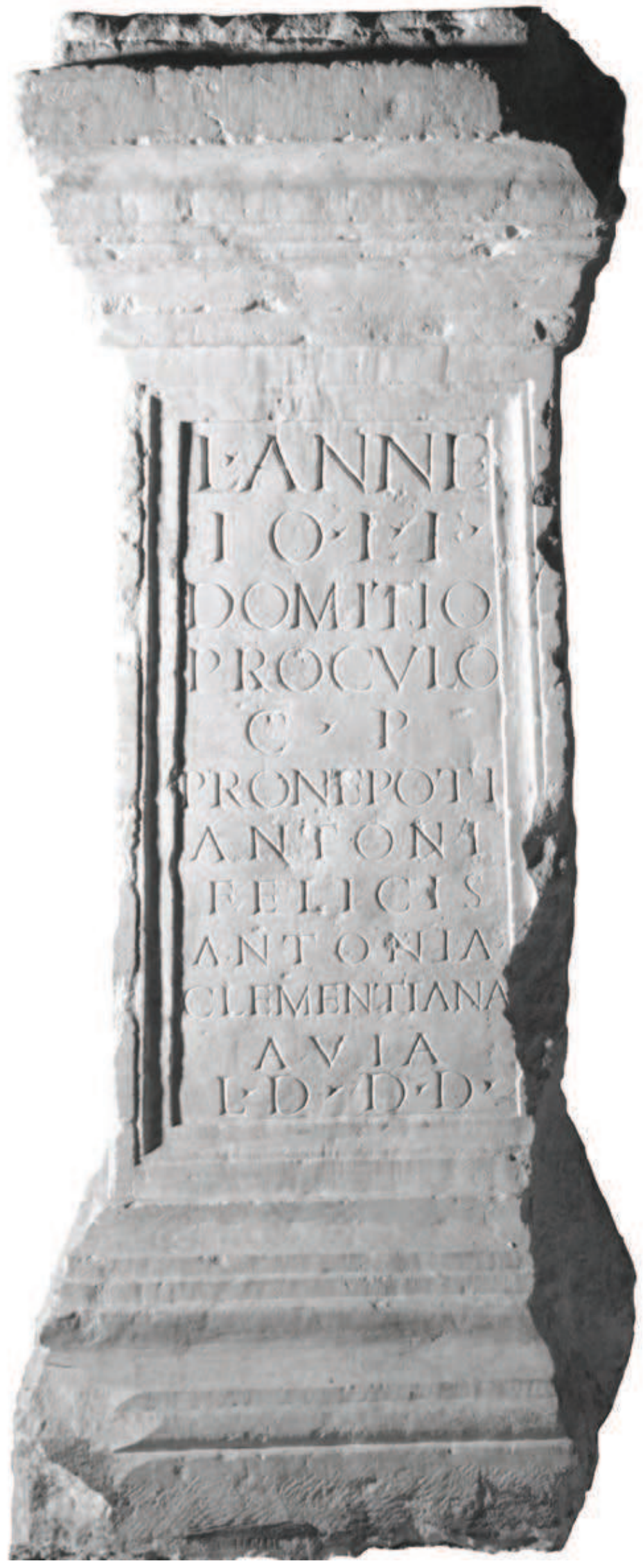


Kameni blok, visine 1,31 m, širine 0,53 m, debljine 0,50 m, bio je baza kipa mladog Lucija Aneja Domicija Prokula, koji je dala podignuti njegova baka Antonija Klementijana, a gradsko vijeće rimske Pule dodijelilo je mjesto za postavljanje tog spomenika, vjerojatno na Forumu. Pritom je Antonija u natpisu koji je naručila naglasila da je Anej Domicije Prokul bio praunuk Antonija Feliksa. lako pojedini elementi njihovih imena zvuče poznato (Antonius, Antonia, Domitius), nisu navedene upravne dužnosti ili počasti triju osoba, no natpis je privukao pažnju Pietra Kandlera, koji je u svojim spisima komentirao povijesni kontekst osoba koje se u njemu spominju (Kandler 1876: 110-112). Natpis se kasnije uzgredno spominje u mnogim epigrafskim i prozopografskim publikacijama, a potanje se na njega osvrnula Alka Starac (Starac 1994, 135-136).

1. Marko Antonije Feliks (M. Antonius Felix, PWRE, 1, 2616-2618) bio je oslobođenik, podrijetlom navodno iz Grčke. Zajedno s bratom Palantom (PWRE, 1, 2634-2635) za Klaudijeve je vladavine dosegao najviše položaje u rimskoj državi: Palant je bio voditelj carskog ureda za financije, a Feliks vojni zapovjednik i potom prokurator Judeje (Suet. Claud. 28). Nisu to bili jedini oslobođenici koji su na carskome dvoru obnašali visoke dužnosti, tako Svetonije spominje još četvoricu (Suet. Claud. 28). Naš se Feliks prema Tacitu zvao Antonius Felix (Hist. 5, 9; usp. Martin 1983, 208; Schwartz 1984, 240-242; Starac 1999, 78-81), a prema Josipu Flaviju M. Claudius Felix (Ant. lud. 20, 7; PIR² A 0620; usp. Kokkinos 1990, 126).

Ako je Tacitov podatak točan, bio bi oslobođenik Antonije, Klaudijeve majke (koja je bila kćerka trijumvira Marka Antonija i Oktavijanove sestre Oktavije, usp. Kokkinos 1992, 6-11), no ako je nosio Klaudijev gentilicij, to bi značilo da je bio kasnije oslobođen, nakon Antonijine smrti 37. godine. lako postoje argumenti za klaudijevsku dataciju Feliksovog oslobađanja, držimo da ipak nema dovoljno razloga za odbacivanje ranije datacije, a time i moguće istovremene manumisije obojice braće. Kako je Antonija preminula 37. godine, to in je oslobodila prije toga, možda oporučno, pa su kao oslobođenici ostali u službi njezina sina Klaudija. Ili je pak Palanta oslobodila za života, a Feliksa oporučno. Odatle možda neusklađenost u podacima Tacita i Josipa Flavija, jer su poslije Antonijine smrti obojica nastavili služiti Klaudiju, pa su vrlo moćni postali (pogotovo Palant) poslije ubojstva cara Kaligule 41. godine, kad je Klaudije bio isklican za cara. Prije 50. godine Feliks je oženio Druzilu (Drusilla, Druzila Mauretanijska mlađa, PWRE, 5, 1741), koju Tacit identificira kao praunuku Kleopatre i Marka Antonija, pa ga optužuje da je „Antoniju Feliks ... unukin muž, a Klaudije unuk" (Tac. Hist., 5, 10), jer je ovaj potonji, kao sin Druza i Antonije, kćeri Marka Antonija i njegove druge supruge Oktavije (sestre Oktavijanove) zaista bio Antonijev unuk (Roller 2003, 251-252). S tom Druzilom Feliks nije imao djece. Bila je potomak ptolomejske dinastije (otac Ptolomej bio je sin mauretanijskog kralja Jube II i Kleopatre Selene, čiji su roditelji bili Marko Antonije (trijumvir) i Kleopatra VII (Roller 2003, 251-252), a poslije očeve smrti do vjenčanja je kao mlada princeza živjela u Rimu na carskome dvoru. Vjenčanje ukazuje i na Feliksov visoki društveni položaj u tom trenutku.

$\mathrm{U}$ pisanim se izvorima Feliks pojavljuje zajedno s bratom Palantom nakon Klaudijeva dolaska na carsko prijestolje 41. godine, i tada počinje njihova karijera na visokim dužnostima. Feliks je najprije obnašao visoke dužnosti u vojnoj hijerarhiji kao zapovjednik kohorti i konjaničkih postrojbi (alae). Nakon toga ga je Klaudije, zacijelo po nagovoru tada već na carskom dvoru vrlo moćnoga mu brata Palanta, imenovao prokuratorom u Samariji, dijelu Judeje kojom je tada upravljala rimska država. O Feliksovu djelovanju kao prokuratora, najmanje od 52. do 58. (a vjerojatno od 50. do 60., Suet. Claud. 28; loseph. Bell. Iud., 2, 12, 8; PIR 659, PIR² A0828), Tacit i Josip Flavije nisu ostavili pozitivne dojmove. U prvo je vrijeme upravljao Samarijom, dok je Galilejom upravljao Ventidije Kuman (Ventidius Cumanus), a 
zajedno su se iskazali u raspirivanju prijestupa, a ne njihovom suzbijanju, tako da je umalo došlo do općeg ustanka. Feliksa je spasio namjesnik Sirije, Umidije Kvadrat (Ummidius Quadratus), koji je vojno intervenirao, ali i zaštitio Feliksa, dok je Kuman osuđen. Tada je Feliks dobio na upravljanje cijelu provinciju Judeju. Godine 54., kad je preminuo car Klaudije, a na prijestolje došao Neron, Feliks je inscenirao razbojnički napad na Ivana, velikog svećenika, koji ga je neprekidno korio zbog lošeg upravljanja pokrajinom (loseph. Ant. lud. 20, 8, 5-6). Zatim je i u Cezareji došlo do nemira između Židova i Sirijaca, koje je Feliks smirio, naredivši intervenciju rimske vojske (loseph. Ant. Iud., 20, 8, 7-8; Bell. Iud. 2, 13, 7).

Dok je upravljao Judejom, Feliks se zaljubio u drugu Druzilu (Drusilla, Druzila judejska PWRE, 5, 1741), i ostavio je svoju prvu ženu. Ova druga istoimena žena bila je kćerka judejskog kralja Heroda Agripe (jer Judeja je još bila klijentelarno kraljevstvo s usporednom rimskom upravom na čijem je čelu bio namjesnik s titulom prokuratora, tj. Feliks), koji ju je nekoliko godina ranije dao za ženu emeškom (Emessa) kralju Azizu (Azizus). Flavije Josip pripovijeda kako se Feliks u nju zaljubio i nagovorio ju da pobjegne od muža (loseph. Ant. Iud. 20, 7, 2) pa su se 55. vjenčali. Iz tog je braka rođen sin Marko Antonije Agripa, koji je s majkom Druzilom stradao u erupciji Vezuva 79. godine (loseph. Ant. Iud. 20, 7, 2).

O trećoj Feliksovoj ženi nije poznato ništa osim da je, kao i prethodne dvije, bila kraljevskog podrijetla (Suet. Claud. 28; usp. Chausson 1997, 686-687). Nije poznato je li Feliks drugu Druzilu napustio (poput prve) ili je treću ženu uzeo poslije 79. Antonije Agripa je sigurno rođen u Feliksovu drugom braku, no je li Antonija Klementijana njegova sestra ili polusestra (kćerka treće žene) ne može se utvrditi.

Feliks je također i onaj prokurator Judeje pred kojega je 57. godine u Cezareju doveden sv. Pavao, nakon što je uhićen u Jeruzalemu (Dj. 21, 27 - 23, 35). Iz biblijskog teksta saznajemo da je Feliks više godina bio namjesnik Judeje i da je dobro poznavao odnos između pravovjernih Židova i sljedbenika Isusa Krista (Dj. 24, 10 i 24, 22) te da mu je žena Druzila bila Židovka (Dj. 24, 24), a i da je bio potkupljiv i da se nadao da će dugotrajnim držanjem sv. Pavla u zatvoru biti podmićen (Dj. 24, 26). Nakon dvije godine, tj. 59/60., Feliks je opozvan $s$ dužnosti prokuratora Judeje, a naslijedio ga je Porcije Fest (koji je odlučio sv. Pavla poslati u Rim). Feliks se vratio u Rim, i tu ga je čelnik cezarejskih Židova (koji je zato i došao u Rim) pred carem optužio da je nemire između Židova i Sirijaca u Cezareji iskoristio kako bi ubijao i pljačkao stanovnike grada. Josip Flavije (Ant. Iud. 20, 8, 9) nedvosmisleno objašnjava da bi Feliks zacijelo bio kažnjen da ga od toga nisu spasila nametljiva uvjeravanja brata Palanta, koji je na Nerona imao jaki utjecaj.

Nije poznato kada je Feliks preminuo. No pulski natpis otkriva da je imao barem jednu kćerku, Antoniju Klementijanu, te po njoj barem jednog unuka, Lucija Aneja Domicija Prokula. Također je pretpostavljeno (Chausson 1997, 686-687) da su M. Antonius Fronto Salvianus, clarissimae memoriae vir, quaestor urbanus, aedilis Cerealis designatus i njegov sin Antonius Félix Magnus, clarissimus puer, s jednog natpisa u Rimu (CIL 6, 1345), možda potomci iste Feliksove loze (a da se potonjega može prepoznati u osobi koja se spominje na jednom drugom natpisu iz Rima, CIL 6, 1984: M. Antonius Fe[...], sodalis Augustalis Claudialis s početka III. stoljeća).

2. Antonija Klementijana (Antonia Clementiana), kćerka Antonija Feliksa i njegove druge (ili treće) žene, poznata je samo s pulskog natpisa, kao njegova naručiteljica. Pisani izvori ju ne spominju, jer iako je bila slobodna žena (ako je bila rođena nakon što je Feliks oslobođen ropstva), nije uživala onaj prvorazredni društveni status koji je pripadao najizloženijim pripadnicima carske obitelji. Osim toga, pretpostavimo li da je bila rođena najranije oko 60. godine, bila je još djevojčica kad je 68. godine Neron počinio samoubojstvo, a nakon kratkog 
nadmetanja više pretendenata (Galba, Oton, Vitelije) na prijestolje je zasjeo rodonačelnik nove dinastije, Tit Flavije Vespazijan (T. Flavius Vespasianus). O njezinu životu ne znamo ništa, osim da je imala potomstvo, ali ju spominju svi suvremeni prozopografski priručnici, u kontekstu Antonija Feliksa, navodeći naš natpis.

3. Lucije Anej Domicije Prokulo (L. Anneius Domitius Proculus), kojemu je pulski natpis posvećen, nosi dva gentilicija, što upućuje na viši društveni položaj obitelji kojoj je pripadao. Navođenje dvaju ili više gentilicija upućuje na adopciju i/ili uzimanje majčinog gentilicija, a obje su pojave u rimskoj društvenoj sredini viših slojeva bile raširene od I. stoljeća (Salomies 1992). Gentilicij Anneius nije osobito čest u rimskoj prozopografiji. Najstariji je spomen jednog uglednog Aneja u pisanim izvorima onaj Ciceronova legata u Ciliciji 51-50. pr. Kr. (Cic. Fam. 13, 55; PWRE, 1, 2225; MRR 2, 244; Neue Pauly 1996, 710), a jedini drugi u prozopografiji poznati Anej je senator iz vremena cara Komoda, Anej Rav (Anneius Rav(u)s, PWRE, 1, 2237; PIR 463; CIL 6, 2010; EDR 128976). Gentilicij bi mogao biti inačica oblika Annaeus, odnosno Annaeius, koje su u prozopografiji i epigrafiji daleko brojnije. Ime je vjerojatno sabinskog porijekla (Neue Pauly 1996, 709), nosi ga nekoliko u rimskoj kulturi znamenitih osoba. Najpoznatiji među Anejima je filozof Lucije Anej Seneka (L. Annaeus Seneca, 4. pr. Kr. - 65. po Kr.; PWRE, 1, 2237-2248; PIR² A 617), ali tu valja spomenuti njegova istoimenog oca (54. pr. Kr. - 39. po Kr.), retora, te starijega brata Lucija Aneja Novata (L. Annaeus Novatus), koji je poslije adopcije uzeo ime L. Junius Gallio Annaeanus (PWRE, 1, 2236-2237). Pod ovim potonjim imenom je u novozavjetnoj historiografiji poznat po tome što je 51-52. godine $u$ Korintu odbacio prijavu židovskih prvaka protiv sv. Pavla (Dj. 18, 12-17).

Zatim je poznat pjesnik Lucije Anej Lukan (L. Annaeus Lucanus, 39-65. godine, PWRE, 1, 2226-2236), autor epskog djela o građanskim ratovima (De bello civili, poznat i pod naslovom Pharsalia). Senekina i Lukanova grana obitelji bile su podrijetlom iz hispanske Kordube (Corduba), dok je još jedna grana bila iz provincije Afrike (Africa Proconsularis). Njoj pripadaju Lucije Anej Flor (L. Annaeus Florus, oko 74. - oko 130; PWRE, 6, 2761-2770), povjesničar aktivan u doba Trajana i Hadrijana, autor Livijevih epitoma (Epitomae de Tito Livio bellorum omnium annorum DCC libri duo), zatim Publije Anej Flor (P. Annaeus Florus), pjesnik i retor Hadrijanova doba. Obje su grane očito činili potomci rimskih kolonista u Hispaniji, odnosno Africi.

Naša inačica gentilicija (Anneius) se u epigrafskim podacima javlja na više spomenika, najviše $u$ Italiji i Hispaniji, no teško in je pouzdano povezati s osobama na našem pulskom natpisu. To su:

- Lucije Letorije Anej Ruf (L. Laetorius L. f. Pob. Anneius Rufus) na natpisu iz Verone (CIL 05, 03407; Alföldy 1984, 130-131, Nr. 208; Alföldy 1999, 285; HD033476; EDR093810),

- Gaj Anej Zenon (C. Anneius Zeno) na natpisu iz Ostije (AE 1948, 0029; HD021522; EDR073670),

- Marko Anej Honorat, Lucije Anej Katul i Markov oslobođenik Marko Aneje Rufije (M. Anneius M. f. Honoratus, L. Anneius M. f. Catulus, M. Anneius M. I. Rufio) iz Lucere u Apuliji (AE 1983, 0220; Bàlice 1981, 10-11, Nr. 10; HD000154; EDR078925),

- Aneja Acilijana (Anneia M. f. Aciliana) iz Peñaflora u hispanskoj Betici (AE 2004, 0751; HD051971),

- Gaj Anej (C. Anneius) s Ibize (AE 1990, 0641; Castelló 1988, 64-66, Nr. 12; HD017496).

Nasuprot tomu, drugi gentilicij, Domitius, vrlo jer čest. Nose ga dvije važne grane te izvorno plebejske obitelji, Domiciji Kalvini i Domiciji Ahenobarbi, ali epigrafija i prozopografija poznaju još više desetaka osoba koje ne možemo svrstati u jednu od njih (PWRE, 5, 1313- 
1520). Kao Domicije Ahenobarb (L. Domitius Ahenobarbus) je bio rođen i sin Agripine Mlađe (PIR I 641) - kasniji car Neron, jer mu je otac bio Gnej Domicije Ahenobarb (PIR² D 127).

Osim navođenja dvaju gentilicija, da je Lucije Anej Domicije Prokul bio pripadnik senatorskog staleža svjedoči i kratica c(larissimus) p(uer). Naslov vir clarissimus (ili clarissimus vir, vrlo poštovani muž) je od kasnorepublikanskog doba bio kolokvijalni počasni dodatak imenu senatora, a početkom II. stoljeća postaje dijelom službene titulature senatora i odmah potom i članova obitelji senatorskog staleža (Gross-Albenhausen 2014), tako da se osim c. vir, za žene i djecu koriste i izrazi c. femina, c. adulescens, c. iuvenis, c. puer, c. puella. Problem klasifikacije točnog značenja izraza puer, puella, iuvenis, adulescens, vir, femina izvire iz činjenice da se radi o općim pojmovima i što dobne granice nisu bile jednoznačno određene (Eyben 1973, 153-163; Parkin 2003, 16). Tako pojam infans, koji označava malo dijete, nalazimo na epigrafskim spomenicima i za osmogodišnjaka (CIL 5, 7409), a puer (dijete) za dvogodišnjaka (CIL 6, 16170), sedmogodišnjaka (AE 1998, 244) i osamnaestogodišnjake (CIL 10, 4022; CIL 14, 5238). Raspon godina na nadgrobnim natpisima koji osobu nazivaju adulescens (mladić?, osoba između dječaštva i zrelosti?) ide od 17 godina (CIL 5, 1926) do 33 godine (CIL 6, 2606), a iuvenis (mladi čovjek, odnosno žena) od 17 godina (AE 1987, 254) do 37 godina (CIL 11, 07848).

Pitanje je stoga kako treba tumačiti izraz (clarissimus) puer (Eyben 1972; Laes \& Strubbe 2014): vjerojatno se odnosi na osobu do oko osamnaeste godine života (Eyben 1981). Međutim, za određivanje okvira moguće datacije natpisa i spomenika Luciju Aneju Domiciju Prokulu važnija je Antonija Klementijana. Ako je bila rođena najranije oko 60. godine (svakako ne prije 55., kad je Antonije Feliks nagovorio Druzilu judejsku da napusti svoga dotadašnjeg supruga), i ako je imala potomstvo dvadeset godina kasnije (oko 80. godine), tada je njezino dijete moglo dobiti sina Lucija Aneja Domicija Prokula oko 100. godine, tako da dolazimo do 120. godine, kad je Antonija Klementijana mogla imati oko 60 godina. No ona je mogla biti rođena i iz trećega Feliksova braka, ali vjerojatno ne poslije 80 . godine, tako da se raspon datacije nastanka našega spomenika širi do 140 . godine. Naravno, to sve pod pretpostavkom da je Antonija imala dijete razmjerno rano, iako to ne možemo znati, tako da taj raspon možemo okvirno proširiti i do 150. Datacija koju je predložio Géza Alföldy (Alföldy 1984, 79; Alföldy 1999, 285: „Ungefähr aus der Mitte des 2. Jahrhunderts“) može se u osnovi potvrditi.

Zanimljivo je da Antonija na natpisu sebe ne naziva kćerkom Antonija Feliksa, već za svoga unuka kaže da je Feliksov praunuk (Antoni Felicis pronepos). Sebe stavlja u drugi plan, ne naglašavajući svoje podrijetlo. U natpisu je naglasak na mladom Luciju, njemu je ponosna baka dala postaviti spomenik uz podršku gradskog vijeća rimske Pule (Colonia Iulia Pola Pollentia Herculanea, kako je poznata iz jednog natpisa u II. stoljeću: CIL 5, 8139; Inscr. It, 10, $1,85)$. To znači da je ona u gradu bila važna ličnost, ali je i Lucije građanima Pule predstavljao sponu s i dalje utjecajnijim klanom Antonijinih oslobođenika.

Osim Antonije Klementijane, u Puli je neko vrijeme boravila i Antonija Cenida (Antonia Caenis), također oslobođenica Antonije Mlađe, koju kao Vespazijanovu priležnicu spominju Svetonije (Vesp., 3, 3; 31, 2) i Kasije Dion (65, 14, 1-4). Svetonije u Domicijanovu životopisu izričito za nju kaže „....kad se vratila iz Istre..." (Domit., $12,3,3)$ pa je oko njezina lika u romantičarskoj historiografiji XIX. stoljeća ispletena potpuno neutemeljena priča da je Vespazijan dao u Puli na njezin nagovor izgraditi kazalište i amfiteatar (Kandler 1876, 126128). Preminula je u Rimu 74. godine, prije Vespazijana, u dobi od oko 60 godina (CIL 06, 12037; PWRE, 2641; PIR², A 888; EDR133813).

O boravku u Puli ovih dviju žena, Antonije Klementijane, kćeri oslobođenika Feliksa koji je dospio u visoko društvo, i Antonije Cenide, oslobođenice koja je bila u službi Antonije, careve majke i bake (a potom i Vespazijanova utjecajna ljubavnica), nema mnogo nedvosmislenih 
podataka iz prve ruke. No zacijelo su ovdje povremeno boravile kako bi nadgledale svoje posjede u južnoj Istri (Starac 1994, 136). Istarska epigrafija pruža podatke za samo sedam osoba s gentilicijem Antonius/Antonia, na šest natpisa (od kojih je jedan natpis i jedna osoba predmet ovoga teksta). Svi su iz Pule i neposredne okolice:

- Antonia Celi... (CIL 5, 115; Inscr. It. 10, 1, 198)

- Antonia Clementiana (CIL 5, 34; Inscr. It. 10, 1, 39)

- C. Antonius Eucarpus (Inscr. It. 10, 1, 199)

- P. Antonius Hilarus (CIL 5, 55; Inscr. It. 10, 1, 423)

- Ant(onia) Severina (CIL 5, 8; Inscr. It. 10, 1, 3)

- M. Antonius Stachus (CIL 5, 115; Inscr. It. 10, 1, 198)

- C. Antonius Zosimianus signo Dalmatius (Inscr. It. 10, 1, 199)

Upadljivo je kako su gotovo sva osobna imena ovih Antonija, muških i ženskih, mahom grčkog podrijetla, što ukazuje na njihov društveni položaj (servilni ili libertinski), a ne na etničko podrijetlo (Solin 1971, 135-137). Svi su dakle ponikli s imanja obitelji Antonija, koji je bilo kako u Istri, tako i u drugim dijelovima Carstva, ali nemoguće je reći tko su točno oni bili. $\mathrm{Ni}$ toponimija nije od velike koristi, jer toponim villa Antoniana zabilježen je samo u jednoj pulskoj srednjovjekovnoj ispravi (1144. godine: Matijašić 1988, 75), kao ime sela koje je bilo napušteno poslije XIV. stoljeća, tako da danas selu ni imenu nema traga. Stoga podrobnosti o povijesti istarskih Antonija ostaje obavijen nedorečenostima na koje podaci koje smo ovdje predočili bacaju samo vrlo skromne tračke svjetla.

\section{POPIS KRATICA}

AE

L'Année épigraphique, Revue des publications épigraphiques relatives à l'antiquité romaine, Paris, od 1888.

CIL Corpus Inscriptionum Latinarum, Berlin, od 1872.

EDH Epigraphic database Heidelberg: http://edh-www.adw.uni-heidelberg.de/ home

EDR Epigraphic Database Rome - www.edr-edr.it

INSCR. IT. Bruna Forlati Tamaro, Inscriptiones Italiae, Vol. X, Regio X, fasc. I-Pola et Nesactium, Roma 1947.

MRR Thomas Robert Shannon Broughton, Magistrates of the Roman Republic, vols. 1-2, New York 1951 (reprint 1968), vol. 3, Atlanta 1986.

NEUE PAUlY Der neue Pauly, Enzyklopädie der Antike, Bd. 1, ed. Hubert Cancik, Helmuth Schneider, Stuttgart - Weimar 1996.

PIR Prosopographia Imperii Romani, Pars I (Buchstaben A - C), ed. Elimarus Klebs, Berlin 1897.

PIR $^{2} \quad$ Prosopographia Imperii Romani, Pars I (Buchstaben A - C), ed. Edmund Groag, Artur Stein, Berlin 1933.

PME

Hubert Devijver, Prosopographia militarum equestrium quae fuerunt ab Augusto ad Gallienum, I Leuven 1976, II 1977, III 1980, IV (Suppl. I), Suppl. S., Leuven 2001.

PWRE Paulys Real-Encyclopädie der classischen Altertumswissenschaft, Neue Bearbeitung, ed. Georg Wissowa, Stuttgart, od 1894. 


\section{POPIS LITERATURE}

\section{ALFÖLDY 1984}

Géza Alföldy, Römische Statuen in Venetia et Histria. Epigraphische Quellen, Heidelberg 1984.

\section{ALFÖLDY 1999}

Géza Alföldy, Städte, Eliten und Gesellschaft in der Gallia Cisalpina, Epigraphisch-historische Untersuchungen, Heidelberg 1999.

\section{BÀLICE 1981}

Maria Bàlice, „Iscrizioni latine di Lucera“, Archivio Storico Pugliese, 34, 1981, 3-39.

\section{CASTELLÓ 1988}

Jaime Juan Castelló, Epigrafía romana de Ebusus, Ibiza 1988.

\section{CHAUSSON 1997}

François Chausson, „Theoclia sœur de Sévère Alexandre", Mélanges de l'Ecole française de Rome. Antiquité, 109, 2, 1997, 659-690.

\section{EYBEN 1972}

Emiel Eyben, „Antiquity's View of Puberty“, Latomus, 31, 1972, 677-697.

\section{EYBEN 1973}

Emiel Eyben, „Die Einteilung des menschlichen lebens im römischen Altertum", Rheinisches Museum für Philologie, 116, 1973, 150-190.

\section{EYBEN 1981}

Emiel Eyben, „Was the Roman ,Youth' an ,Adult' Socially?", L'Antiquité Classique, 50, 1981, 328350.

\section{GROSS-ALBENHAUSEN 2014}

Kirsten Groß-Albenhausen, „Vir clarissimus", Der Neue Pauly, Hubert Cancik, Helmuth Schneider (Antike), Manfred Landfester (Rezeptions- und Wissenschaftsgeschichte), http:// referenceworks.brillonline.com/entries/derneue-pauly/vir-clarissimus-e12205430 (26. travnja 2014.)

\section{KANDLER 1876}

Pietro Kandler, Notizie storiche di Pola edite per cura del Municipio e dedicate agli onorevoli membri della Società Agraria Istriana radunati al IX Congresso Generale nella Città di Pola, Parenzo 1876.

\section{KOKKINOS 1990}

Nikos Kokkinos, „A fresh look at the gentilicium of Felix procurator of Judaea", Latomus 49, 1990, 126-141.

\section{KOKKINOS 1992}

Nikos Kokkinos, Antonia Augusta: Portrait of a great roman lady, London 1992.

\section{LAES \& STRUBBE 2014}

Christian Laes, Johan Strubbe, Youth in the Roman Empire: The Young and the Restless Years, Cambridge University Press, Cambridge 2014. (izv. Jeugd in het Romeinse Rijk: Jonge jaren, wilde Haren? Davidsfonds, Leuven 2008)

\section{MARTIN 1983}

Alain Martin, „T. Mucius Clemens, praefectus castrorum d'Agrippa II", Zeitschrift für Papyrologie und Epigraphik, 52, 1983, 203-210.

\section{MATIJAŠIĆ 1988}

Robert Matijašić, Ageri antičkih kolonija Pola i Parentium i njihova naseljenost od I. do III. stoljeća, Zagreb 1988.

\section{PARKIN 2003}

Tim G. Parkin, Old Age in the Roman World: A Cultural and Social History. Baltimore, Baltimore 2003.

\section{ROLLER 2003}

Duane W. Roller, The World of Juba II and Kleopatra Selene: Royal scholarship on Rome's african frontier, London 2003.

\section{SALOMIES 1992}

Ollija Salomies, Adoptive and Polyonymous Nomenclature in the Roman Empire, Helsinki 1992.

\section{SCHWARTZ 1984}

Seth Schwartz, „T. Mucius Clemens, commander of the army of Agrippa II", Zeitschrift für Papyrologie und Epigraphik, 56, 1984, 240-242. 


\section{SOLIN 1971}

Heikki Solin, Beiträge zur Kenntnis der griechischen Personennamen in Rom, I, Commentationes Humanarum Litterarum, Societas Scientiarum Fennica, 48, Helsinki 1971.

\section{STARAC 1994}

Alka Starac, "Carski posjedi u Histriji“, Opuscula Archaeologica, 18, 1994., 133-145.

\section{STARAC 1999}

Alka Starac, Rimsko vladanje u Istri i Liburniji, I, Histrija, Monografije i katalozi, 10/1, Pula 1999.

\section{SAŽETAK}

Počasni antički natpis na postolju kipa koji je početkom XIX. stoljeća pronađen u Puli, spominje tri osobe: dala ga je izraditi Antonija Klementijana (Antonia Clementiana) u čast svom unuku Luciju Aneju Domiciju Prokulu (L. Anneius Domitius Proculus), koji je bio i praunuk Antonija Feliksa (Antonius Felix). Ovaj potonji je bio poznati oslobođenik Antonije Mlađe, nećakinje cara Augusta, kćeri trijumvira Marka Antonija s njegovom sestrom Oktavijom, koji je kao vojni časnik služio u vrijeme cara Klaudija, koji ga je oko 50. godine imenovao namjesnikom Judeje. Njegov brat je bio još poznatiji Palant (Antonius Pallas), upravitelj financija na Klaudijevu carskom dvoru. Kako Feliksa neki izvori nazivaju Antonijem (Tacit), a drugi Klaudijem (Josip Flavije), među znanstvenicima nema suglasja o njegovu pravom oslobođeničkom imenu. Bit će da ga je Antonija oslobodila oporučno, pa je slobodan postao za Klaudija, kojega je nastavio služiti, tako da postoje obje tradicije njegova imena.

Feliks je imao tri žene, od kojih je prvu napustio, s drugom je imao dvoje djece, a o trećoj se ne zna ništa. Kao namjesnik je u Judeji u nekoliko navrata izazvao konfliktne situacije, što opisuje Josip Flavije, a spominje se i u Djelima apostolskim: to je onaj namjesnik pred kojega je doveden uhićeni sv. Pavao. Feliks ga je držao u zatvoru dvije godine, sve dok nije bio razriješen dužnosti (a tada ga je njegov nasljednik poslao u Rim pred cara). Druga je Feliksova žena bila Druzila, kćerka judejskog kralja Heroda Agripe, koja je sa starijim Feliksovim sinom, Markom Antonijem Agripom, stradala 79. godine u erupciji Vezuva. Mlađa kći Antonija Klementijana je naručiteljica našega natpisa, čiji je unuk bio naš Anej Domicije Prokul.

Ta najmlađa osoba na natpisu se spominje kao clarissimus puer, što znači da je bio dijete i potomak obitelji senatorskog staleža. Upravo taj izraz određuje njegov društveni status, odnosno status njegovih nepoznatih nam roditelja. Ako je Antonija bila rođena najranije oko 60. godine (svakako ne prije 55.), i ako je imala potomstvo dvadeset godina kasnije (oko 80. godine), tada je njezino dijete moglo dobiti sina Lucija Aneja Domicija Prokula oko 100. godine, tako da dolazimo do 120. godine, kad je Antonija Klementijana mogla imati oko 60 godina. No ona je mogla biti rođena i iz trećega Feliksova braka, ali vjerojatno ne poslije 80. godine, tako da se raspon datacije nastanka našega spomenika širi do 140. godine. Naravno, to je sve pod pretpostavkom da je Antonija imala dijete razmjerno rano, iako to ne možemo znati, tako da taj raspon možemo okvirno proširiti i do 150-160. Datacija koju je predložio Géza Alföldy (sredina II. stoljeća) može se tako u osnovi potvrditi.

Antonija Klementijana kao naručiteljica u natpisu ne spominje detalje svojega podrijetla, niti počasti koje je uživao njezin otac Antonije Feliks, već je u natpisu naglasak na mladom Luciju, kojemu je ponosna baka dala postaviti spomenik uz podršku gradskog vijeća rimske Pule. Ona je u gradu očito bila važna ličnost, ali je i Lucije građanima Pule predstavljao 
sponu s utjecajnim klanom Antonijinih oslobođenika i oslobođenica. Oni su u Puli zacijelo povremeno boravili kako bi nadgledali svoje posjede u južnoj Istri. Njihovi su oslobođenici bili oni Antoniji koji se spominju na epigrafskim spomenicima, ali gdje su točnije bili ti posjedi, nije danas poznato.

\section{RIASSUNTO}

\section{Note su Lucio Anneio Domizio Proculo dall'iscrizione polese CIL 5, 34}

L'iscrizione in questione, incisa su una base destinata ad una statua onorifica e rinvenuta a Pola all'inizio dell'Ottocento, menziona tre persone: venne infatti commissionata da Antonia Clementiana in onore del nipote Lucio Anneio Domizio Proculo, che vi viene indicato quale pronipote di Antonio Felice (Antonius Felix). Quest'ultimo fu il noto liberto di Antonia Minore, nipote dell'imperatore Augusto e figlia di Marco Antonio il triumviro e di Ottavia, sorella di Ottaviano (in seguito Augusto). Egli fu dapprima ufficiale dell'esercito, e venne successivamente nominato procuratore della Giudea dall'imperatore Claudio attorno al 50 d.C. Suo fratello era il più noto Pallante, preposto alle finanze delle corti di Claudio e Nerone. Felice viene detto Antonius da Tacito, ma Claudius da Giuseppe Flavio, cosicché non v'è certezza circa il suo vero nome. Può darsi che Antonia avesse liberato dapprima Pallante e successivamente Felice, per testamento, cosicché ambedue continuarono a servire Claudio.

Felice ebbe tre mogli; di queste, ripudiò la prima, con la seconda ebbe due figli, mentre della terza nulla si sa. Come procuratore della Giudea non fu in grado - come ricorda Flavio Giuseppe- di placare le animosità esistenti tra la popolazione locale ed i Romani. Menzionato anche negli Atti degli Apostoli, Felice fu quel procuratore dinanzi al quale venne condotto San Paolo, che venne poi da lui tenuto in prigione per due anni, finché il suo successore non lo inviò a Roma. La seconda moglie di Felice fu Drusilla, figlia del re giudeo Erode Agrippa, morta nell'eruzione del Vesuvio assieme al figlio Marco Antonio Agrippa. La figlia minore di Antonio Felice e Drusilla fu, appunto, la nostra Clementiana, che andò sposa ad un Anneio col quale ebbe un figlio dal quale nacque Lucio Anneio Domizio Proculo (alternativamente, è anche possibile pensare che sia andata moglie ad un Domizio col quale avrebbe avuto una figlia, madre di Proculo).

Il giovane Anneio viene definito clarissimus puer, il che significa che era di famiglia senatoria, e ciò definisce il suo status sociale, anzi quello dei suoi genitori, a noi altrimenti ignoti. Se Antonia nacque attorno al 60 d.C. (certamente, comunque, non prima del 55), e se procreò circa venti anni più tardi (cioè attorno all' 80 d.C.), il di lei figlio (o la di lei figlia) non può avere a sua volta procreato Lucio Anneio Domizio Proculo prima del 100 d.C. Arriviamo così al 120 d.C. come terminus post quem per la datazione della nostra iscrizione, quando Antonia Clementiana poteva avere circa 60 anni di età. Si può tuttavia anche pensare che ella possa esser nata dal terzo matrimonio di Felix, che verosimilmente ebbe luogo non dopo l'80 d.C. In tal caso il terminus slitterebbe al 140 d.C. È d'altra parte concepibile anche che Antonia possa aver partorito il genitore del Nostro anche in età più matura, così che la datazione può essere estesa fino al 150-160 d.C. La datazione proposta da Géza Alföldy (attorno alla metà del II secolo) viene così sostanzialmente confermata.

Nell'iscrizione, Antonia Clementiana non fa riportare alcun dettaglio sulla propria discendenza, né sulle cariche pubbliche ricoperte da suo padre Antonio Felice. L'accento è esclusivamente sul giovane Lucio, al quale la nonna ha fatto erigere il monumento con l'appoggio dell'ordine dei decurioni di Pola romana. Antonia era evidentemente una persona 
importante, ma anche la figura di Lucio rappresentava per i cittadini di Pola un legame con I'influente clan dei liberti di Antonia Minore. Questi soggiornavano certamente a Pola con una certa frequenza, per poter controllare i propri beni nell'Istria Settentrionale. I loro liberti sono gli Antonii che compaiono sulle iscrizioni romane, ma non ci è dato di sapere con precisione dove i loro possedimenti fossero ubicati.

Parole chiave: Istria, antichità, epigrafia, prosopografia, Antonia Minor, Annei 